\title{
LYSOSOMAL ENZYMES IN THE ACROSOME AND THEIR POSSIBLE RÔLE IN FERTILIZATION
}

\author{
A. G. ALLISON* AND E. F. HARTREE $\dagger$ \\ *Clinical Research Centre Laboratories, \\ National Institute for Medical Research, London, N.W.7, and \\ †A.R.C. Unit of Reproductive Physiology and Biochemistry, \\ University of Cambridge
}

(Received 25th February 1969)

\begin{abstract}
Summary. Ram spermatozoa were washed with hypotonic tris- $\mathrm{HCl}$ buffer and obtained almost free of seminal plasma and cytoplasmic droplets. Acrosomes were dislodged by incubating the spermatozoa with a cationic detergent (Hyamine 2389). The acrosomal preparation and the buffer washings were examined for the following lysosomal enzymes: acid phosphatase, aryl sulphatase, $\beta-\mathcal{N}$-acetylglucosaminidase, phospholipase A and proteases. All enzyme activities were detected, both in washings and in acrosomal preparations. The levels of activity in the latter were much higher than could be expected on the assumption that all activities were due to contamination by washings. Protease activity was greatest at $\mathrm{pH} 7 \cdot 5$.

After vital staining with Euchrysine 3R, acrosomal fluorescence in ram, bull, boar and human spermatozoa is not very conspicuous. However, acrosomes of guinea-pig, hamster and several rodents show the brilliant orange-red fluorescence typical of lysosomes. As spermatids mature, red-fluorescing granules around the Golgi zone condense to form the red-fluorescent pro-acrosomes.

Acid phosphatase was detectable histochemically in granules, proacrosomes, acrosomes and the pellets obtained by high-speed centrifugation of acrosomal preparations. At all developmental stages, histochemical tests for bromochloroindoxyl acetate esterase showed that this enzyme was present only in the acrosome.
\end{abstract}

The evidence suggests that the acrosome is a specialized lysosome which evolved to facilitate fertilization in multicellular organisms.

\section{INTRODUCTION}

In most animal forms, the nucleus of the spermatozoon is capped by a characteristic organelle, the acrosome, the structure and disposition of which varies from species to species (Bishop \& Walton, 1960; Colwin \& Colwin, 1967). If rat and guinea-pig spermatozoa are vitally stained with aminoacridines, the

† Postal address: Animal Research Station, 307 Huntingdon Road, Cambridge CB3 0JQ. 
acrosome shows a red fluorescence (Bishop \& Smiles, 1957, 1963) which is similar to that exhibited by lysosomes in other cells (Allison \& Young, 1964). The development by Hartree \& Srivastava (1965) of a procedure for detaching acrosomes from mammalian spermatozoa by means of the cationic detergent Hyamine 2389 suggested a possible approach to determining whether the acrosome has enzymes characteristic of lysosomes and to analysis of the rôle of such enzymes in the interaction of male and female gametes. The acrosomal lipoglycoprotein complex, prepared by treating ram spermatozoa with this detergent, shows hyaluronidase and protease activities. These enzymes are characteristic components of lysosomes (Aronson \& Davidson, 1965, 1968; Bouma \& Gruber, 1964; de Duve \& Wattiaux, 1966; Hutterer, 1966; Vaes, 1967; Filipović \& Buddecke, 1968). Furthermore, their presence in acrosomal lipoglycoprotein preparations appears to be responsible for the ability of such preparations to bring about dispersion of follicular cells that surround freshly ovulated rabbit eggs and dissolution of the zona pellucida (Srivastava, Adams \& Hartree, 1965).

In our early experiments, several typical lysosomal enzymes were detected in acrosomal lipoglycoprotein preparations from ram spermatozoa. However, the validity of such results was rendered uncertain (i) by the discovery of Dott \& Dingle (1968) that the cytoplasmic droplets in ram and bull spermatozoa carry hydrolytic enzymes of lysosomal type, and (ii) by our subsequent observation that the droplet:spermatozoon ratio could be as high as 0.2 in the suspension of washed spermatozoa used for making the acrosomal lipoglycoprotein complex. We have therefore devised a method for obtaining ram spermatozoa virtually free from droplets and from any particulate breakdown-products of droplets. In this paper, the experiments which led to an improved method for isolating acrosomal lipoglycoprotein solutions from droplet-free ram spermatozoa are summarized. The solutions will be referred to as 'acrosomal preparations'. Such preparations contain a number of typical lysosomal enzymes. These results are discussed in relation to histochemical studies of acrosomes and the possible rôle of enzymes of lysosomal type in fertilization.

A preliminary account of this work has been published (Allison \& Hartree, 1968).

\section{MATERIALS AND METHODS}

Hyamine 2389 (methyl dodecyl benzyltrimethylammonium chloride and methyl dodecyl xylene-bis-trimethylammonium chloride) was obtained from British Drug Houses Ltd. Bovine haemoglobin (for assay of proteolytic enzymes) was obtained from Armour Pharmaceutical Co., glycylphenylalaninamide from Yeda Research Development Corporation, lecithin from Koch-Light Laboratories, and other enzyme substrates, including 5-bromo-4-chloroindoxyl acetate, from Sigma Chemical Co. Euchrysine 3R was supplied by G. T. Gurr Ltd and glutaraldehyde (electron microscopy grade) by TAAB Laboratories, Emmer Green, Reading. Each sample of ram semen consisted of the pooled ejaculates collected by artificial vagina from about twenty rams. Pooled semen from six vasectomized rams was kindly supplied by $\mathrm{Dr} \mathrm{H}$. M. Dott. Samples of bull and boar semen were collected by artificial vagina, human semen was 
from recent ejaculates and guinea-pig, hamster and rodent spermatozoa were expressed from the vas deferens.

Fractionation of semen: isolation of acrosomal preparations

The finally standardized procedure is set out in Scheme 1.

As wash fluid for spermatozoa, the sperm-Ringer originally used (Mann, 1946; Hartree \& Srivastava, 1965) was replaced by $50 \mathrm{~mm}$-tris containing $\mathrm{NaOH}$ to $\mathrm{pH} 7 \cdot 4$. This hypotonic buffer immobilizes spermatozoa (R. A. P. Harrison, personal communication) while tris increases the fragility of cytoplasmic droplets (Dott \& Dingle, 1968).

Spermatozoa were washed at $20^{\circ} \mathrm{C}$ in the MSE Superminor centrifuge fitted with wind-shield and swing-out buckets to take $15-\mathrm{ml}$ glass tubes. A Pasteur pipette was used, both for removing supernatant fluids and for resuspending packed spermatozoa. Up to twelve 2-ml portions of ram semen were each suspended in $10 \mathrm{ml}$ of wash-fluid. After $5 \mathrm{~min}$, the tubes were centrifuged for $15 \mathrm{~min}$ at $425 \mathrm{~g}$. (For the first minute, the rheostat was set for $2 \times 425 \mathrm{~g}$ in order to accelerate the head quickly to the required speed.) The packed cells in each tube were washed three times with $10-\mathrm{ml}$ portions of buffer under the following conditions: $10 \mathrm{~min}$ at $425 \mathrm{~g}, 10 \mathrm{~min}$ at $325 \mathrm{~g}, 7 \mathrm{~min}$ at $325 \mathrm{~g}$. The first washing contained the bulk of the droplets and smaller particles, and also some detached tails which are normally present in fresh ram semen. The fourth washing contained very small numbers of spermatozoa and droplets. The overall recovery of spermatozoa after washing was 83 to $86 \%$, on the basis of turbidity.

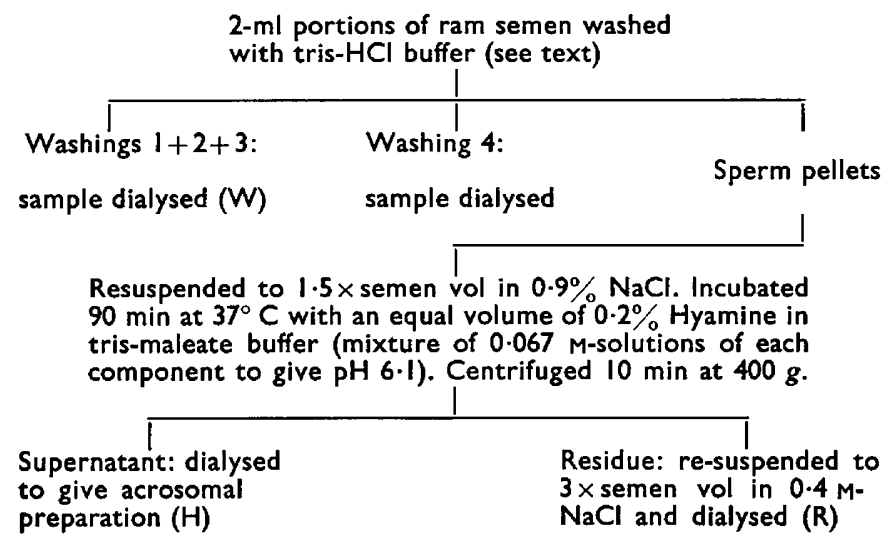

SCHEME 1. Fractionation of ram semen to provide acrosomal preparations from dropletfree spermatozoa. All dialyses were against $0.4 \mathrm{~m}-\mathrm{NaCl}$ for $6 \mathrm{hr}$.

Citrate, a marker for seminal plasma (Mann, 1964), could not be detected in the washed spermatozoa: at least $99.6 \%$ had been removed in the washings. No particles, other than spermatozoa and droplets, were visible under phase contrast and the ratio droplets:spermatozoa was 0.009 to 0.013-1 (Pl. 1, Figs. 1 and 2).

Procedures for detachment of acrosomes with Hyamine and for collecting acrosomal preparations $(\mathbf{H})$ are modifications of the original method (Hartree \& Srivastava, 1965). The recovery of acrosomes in the supernatant fraction 
after Hyamine treatment was 50 to $60 \%$, the remainder being present in the residue $(R)$, where most were still attached to heads.

To obtain seminal plasma free from particulate matter, ram semen was centrifuged for $15 \mathrm{~min}$ at $1000 \mathrm{~g}$. The upper third of the tube contents was re-centrifuged for $30 \mathrm{~min}$ at $15,000 \mathrm{~g}$. Semen from vasectomized rams was also centrifuged at $15,000 \mathrm{~g}$ to remove débris.

\section{Analytical methods}

DNA was analysed by the method of Burton (1956). All enzyme assays were performed at $37^{\circ} \mathrm{C}$. Malate dehydrogenase, a typical mitochondrial enzyme, was assayed as described by Mehler, Kornberg, Grisolia \& Ochoa (1948). Proteolysis was measured with denatured haemoglobin as substrate (Press, Porter \& Cebra, 1960). Units are $\Delta E_{280} / 30 \mathrm{~min}$ calculated back to $1 \mathrm{ml}$ of semen; in other words, calculated back to the volume of sample that would be obtained from $1 \mathrm{ml}$ of semen. Tests for cathepsins B and C were carried out with benzoylargininamide and glycylphenylalaninamide respectively (Bouma \& Gruber, 1964).

Other enzyme activities are expressed as $\mu$ moles of substrate hydrolysed/ 30 min calculated back to $1 \mathrm{ml}$ of semen. Acid phosphatase (AP) was measured by a standard procedure (Bergmeyer, 1963), except that citrate buffer was replaced by $0.25 \mathrm{~m}$-acetate, $\mathrm{pH} 4.5 . \beta$ - $\mathcal{N}$-acetylglucosaminidase $(\beta \mathrm{A})$ was assayed according to Findlay, Levvy \& Marsh (1958) and aryl sulphatase (AS) according to Roy (1955), using 0.2 M-nitrocatechol sulphate. Phospholipase A (PLA) was measured by the procedure of Gallai-Hatchard \& Thompson (1965): appropriate blanks were run to compensate for the presence of endogenous phospholipase substrates.

\section{Cytology and histochemistry}

Vital staining of spermatozoa and of spermatids in suspensions of guinea-pig vas deferens and testis cells was carried out in collaboration with $\mathrm{Mr} \mathrm{M}$. R. Young (Allison \& Young, 1964). Gells were well mixed with sperm-Ringer or with Baker's medium containing 1:50,000 to 1:500,000 Euchrysine 3R, incubated at $37^{\circ} \mathrm{C}$ for $30 \mathrm{~min}$ in the dark, gently centrifuged and re-suspended in fresh medium for fluorescence microscopy. To detect acid phosphatase, unfixed specimens and specimens that had been fixed in formol-calcium or in 0.05 M-cacodylate buffer $(\mathrm{pH} 7.0)$ containing $1.5 \%$ glutaraldehyde were incubated in Gomori medium (Allison \& Mallucci, 1965) or according to Burstone (1961). The same two reactions were carried out on $H$ fractions. These were centrifuged at $25,000 \mathrm{~g}$ and the pellets were fixed and stained in the centrifuge tubes. Indigogenic esterase was studied by the method of Holt (1958). For the periodic acid-Schiff (PAS) reaction, the procedure of Pearse (1968) was followed.

\section{RESULTS}

Variations in the procedure for obtaining acrosomal preparations: effects upon the activities of $A P, A S$ and $\beta A$

In the original procedure for the detachment of ram acrosomes, a suspension 
PLATE 1
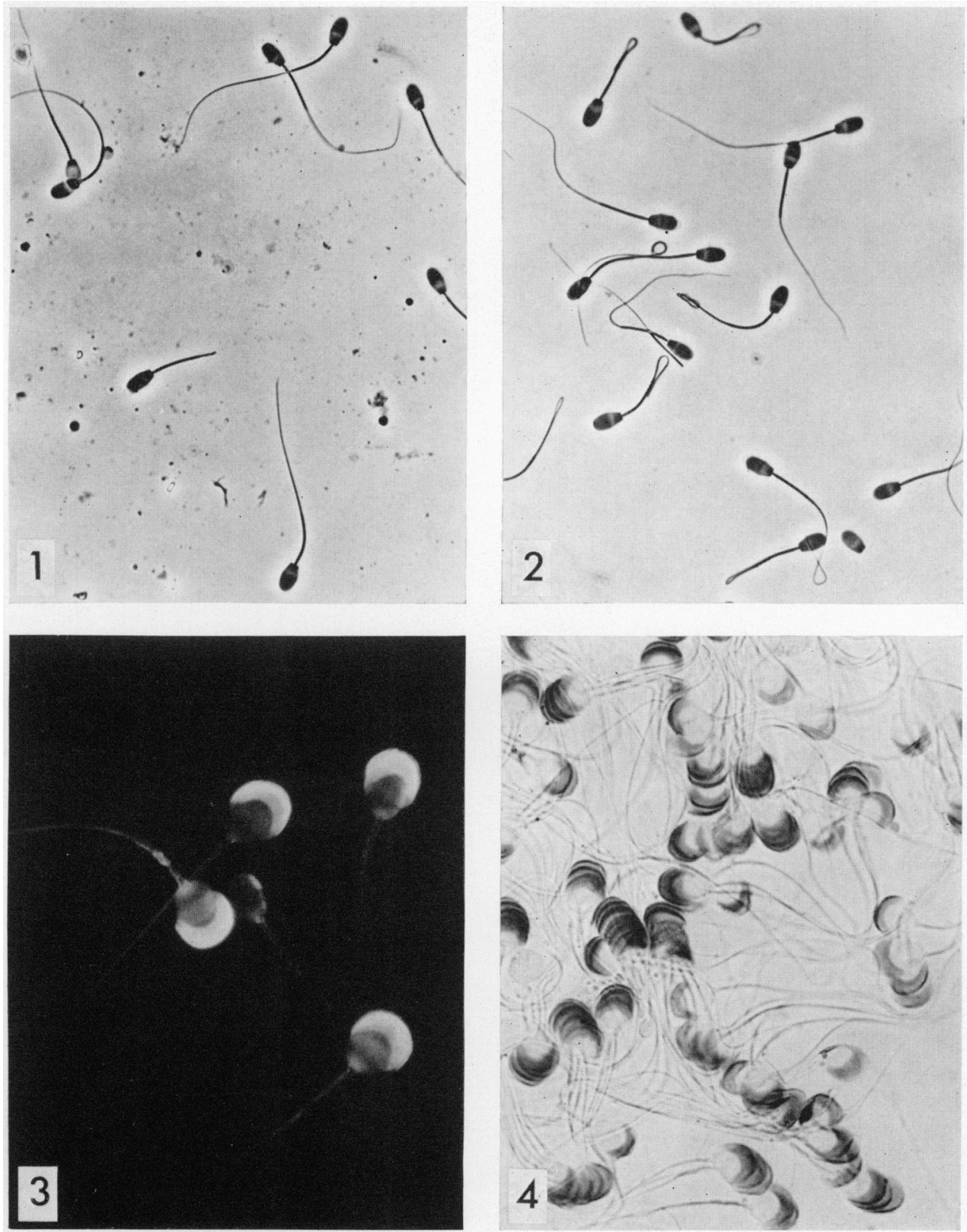

Fig. 1. Ram semen diluted in formol saline ( $\times 590$; phase contrast).

Fig. 2. Ram spermatozoa (in formol saline) after being washed with tris- $\mathrm{HCl}$ buffer as in Scheme 1 ( $\times 590$; phase contrast).

Fig. 3. Fluorescence photomicrograph of guinea-pig spermatozoa after vital staining with Euchrysine $(\times 860)$. The acrosome fluoresces brilliant orange (pale in half tone), the nucleus green.

Fig. 4. Guinea-pig spermatozoa fixed in glutaraldehyde for $15 \mathrm{~min}$ and stained for chlorobromoindoxyl acetate esterase $(\times 525)$. The blue reaction product is confined to the acrosome.

(Facing p. 504) 
of washed spermatozoa was incubated with an equal volume of $0.1 \%$ Hyamine in phosphate buffer (Hartree \& Srivastava, 1965). To determine whether these were optimum conditions for recovery of enzymes in the $\mathbf{H}$ fraction, and also to assess the possible contributions of non-acrosomal enzymes to the measured activities in $\mathbf{H}$ fractions, the experiments summarized in Table 1 were carried out. The experimental procedure was as in Scheme 1, except that (i) dialysis was for $40 \mathrm{hr}$; (ii) to prepare $\mathrm{Hl}$, the washed sperm suspension was incubated for 90 min with an equal volume of $0.1 \%$ Hyamine in $0.15 \mathrm{M}$-phosphate buffer, pH 6.1 (Hartree \& Srivastava, 1965); (iii) to prepare H2, a replicate incubation was carried out, then more (undiluted) Hyamine was added to double its concentration, and incubation was continued for a further $60 \mathrm{~min}$.

TABLE 1

ACTIVITY OF ENZYMES AP, AS AND $\beta$ A IN SEMEN FRAGTIONS AND IN AGROSOMAL FRAGTIONS Hl AND H2

\begin{tabular}{|c|c|c|c|}
\hline & $A P$ & $A S$ & $\beta A$ \\
\hline $\begin{array}{l}\text { Washings } 1+2+3(\mathrm{~W}) \\
\text { Washing } 4 \\
\text { Seminal plasma } \\
\text { Acrosomal preparation } \mathrm{H} 1 \\
\text { Acrosomal preparation } \mathrm{H} 2\end{array}$ & $\begin{array}{r}39 \cdot 7 \\
0 \cdot 7 \\
27 \cdot 0 \\
7 \cdot 8 \\
9 \cdot 2\end{array}$ & $\begin{array}{r}25 \cdot 3 \\
0 \cdot 8 \\
24 \cdot 1 \\
0 \cdot 6 \\
1 \cdot 0\end{array}$ & $\begin{array}{c}237 \\
4 \cdot 5 \\
136 \\
16 \cdot 8 \\
14 \cdot 6\end{array}$ \\
\hline $\begin{array}{l}\text { Calculated contribution by non-spermatozoal } \\
\text { material to the enzyme activities of } \mathrm{H} 1 \text { or } \mathrm{H} 2 \\
\text { assuming that such material derives from } \\
\text { (1) droplets } 0.01(\mathrm{a}+\mathrm{b}-\mathrm{c})^{*} \\
\text { (2a) seminal plasma } 0.006 \mathrm{c}^{*} \\
\text { (2b) seminal plasma } 0.09 \mathrm{~b} \dagger\end{array}$ & $\begin{array}{l}0.13 \\
0.16 \\
0.07\end{array}$ & $\begin{array}{l}0.02 \\
0.14 \\
0.08\end{array}$ & $\begin{array}{l}1.0 \\
0.82 \\
0.5\end{array}$ \\
\hline
\end{tabular}

Results are expressed as $\mu$ moles of substrate cleaved $/ 30$ min at $37^{\circ} \mathrm{C}$ calculated back to $1 \mathrm{ml}$ of semen

* On the basis of volumetric relationships between packed cells and supernatant fluids, washings $1+2+3$ should remove not less than $99.8 \%$ of seminal plasma and of very small particles. After four washings, the level of citrate, and therefore of plasma, was reduced to not more than $0.6 \%$ : at the same stage? the droplet:spermatozoa ratio had fallen to about 0.01 . It can, thus, be assumed that contamination of $\mathbf{H}$ fractions by droplet fraction is $<1 \%$ in relation to whole semen.

$\uparrow$ The value 0.09 expresses the ratio $(1: 11)$ of the volume of wash fluid contained in the pellet after the fourth wash to the final volume of the $\mathrm{H}$ fraction.

The more drastic treatment with Hyamine (leading to H2) gave higher yields of $\mathrm{AP}$ and $\mathrm{AS}$ but a lower yield of $\beta \mathrm{A}$. Although the activities of $\mathrm{Hl}$ and $\mathrm{H} 2$ represent small fractions of total semen activities, we consider that they cannot be ascribed to non-spermatozoal contamination. Contamination can be due to droplets and to seminal plasma. The enzyme activities of droplets in semen may be taken as the difference between activities of washings and of seminal plasma. Thus, the extent of contamination of $\mathrm{H}$ fractions by droplets, in terms of enzyme activities, may be calculated (Table 1). An uncertainty in estimating the contribution of plasma enzymes to the activities of $\mathrm{H}$ fractions is the possible instability of droplets. Thus, Dott \& Dingle (1968) found that the AP activity in the washings of bull cytoplasmic droplets was, to a considerable extent, present in very small particles that would sediment only at $100,000 \mathrm{~g}$. 
On the other hand, ram seminal plasma is apparently free from such particles since when it is re-centrifuged at $100,000 \mathrm{~g}$, virtually all of the AP, AS and $\beta \mathrm{A}$ activities remain in the supernatant fluid.

Two methods for calculating the extent of contamination by seminal plasma are possible (Table 1). Method $2 \mathrm{a}$ is based upon the measured activity of plasma freed from very small particles. Method $2 b$ is based upon the activity of Washing 4. If droplets break during the four-fold wash procedure, Method $2 \mathrm{~b}$ would, in fact, give values for contamination by plasma plus particles. But as values obtained by method $2 b$ are lower than those obtained by Method 2a, small particle contamination must be very low. It is therefore concluded that the true values for $\mathrm{AP}$ and $\beta \mathrm{A}$ in $\mathrm{H1}$ and $\mathrm{H} 2$ are close to the measured values. A similar conclusion about AS activities cannot be drawn from Table 1. However, inorganic phosphate is an inhibitor of AS (Roy, 1955) and when the use of phosphate was eliminated, values for AS activity were higher (as in Table 2) and therefore unlikely to be due entirely to non-spermatozoal contamination. Further experiments showed that a shorter dialysis $(6 \mathrm{hr})$ yielded higher activities of some enzymes. Thus, the activity of PLA fell progressively during more prolonged dialysis. A similar behaviour of phospholipase $\mathbf{B}$ has been reported (Beare \& Kates, 1967).

Effects of different procedures for washing spermatozoa on the enzymatic activities of fractions derived from ram semen

Four parallel experiments $(3,4,5,6)$ were carried out. For Exp. 3, the procedure was as in Scheme 1. In Exps. 4 and 5, the only modifications were in the wash-media. Tris- $\mathrm{HCl}$ containing $2.5 \mathrm{~mm}$-EDTA and $2.5 \mathrm{~mm}$-mercaptoethanol was used for Exp. 4 and sperm-Ringer diluted with 2 vol of water for Exp. 5. For Exp. 6, spermatozoa were washed twice with sperm-Ringer (Hartree \& Srivastava, 1965). The fractions W, H, and R were tested for PLA when fresh, then stored at $-20^{\circ} \mathrm{C}$ for 2 days. (Activity of PLA was reduced by freezing). When $\mathrm{R}$ fractions were thawed, they flocculated. They were then centrifuged to give clear supernatant fractions ( $R$-su) and particulate fractions that were re-suspended in $0.4 \mathrm{M}-\mathrm{NaCl}$ and dispersed by brief sonication (R-pa).

Results of assays in Exps. 3 and 4 are shown in Table 2. Activities of AP, $\beta A$ and PLA in the corresponding fractions from the two experiments showed no marked difference. The results of AS analyses were variable. In Exp. 3, AS activities were scarcely affected by freezing and thawing. In Exp. 4, freezing led to losses in activity although in a repeat experiment, no such losses were observed. In all experiments, R-pa fractions were devoid of AS activity.

Exp. 5 yielded fractions with AP activities similar to those of Exp. 4; however, PLA activities were very low. In Exp. 6, AP and PLA activities in the $H$ fraction were higher than in Exps. 3 to 5 . This was expected since the washed spermatozoa for this experiment were not free from cytoplasmic droplets.

Proteolytic activity of fractions obtained during the isolation of acrosomal preparations from ram spermatozoa

Proteolytic activity of the $\mathrm{W}, \mathrm{H}$ and $\mathrm{R}$ fractions, as determined with haemo- 
globin, declined on storage even at $-20^{\circ} \mathrm{C}$. The following experiments were therefore carried out not more than $2 \mathrm{hr}$ after dialysis for $6 \mathrm{hr}$.

TABLE 2

ENZYME ACTIVITIES IN FRACTIONS FROM EXP. 3 AND 4 IN WHICH SPERMATOZOA HAD BEEN WASHED RESPECTIVELY WITH TRIS-HCL AND WITH TRIS-HGLEDTA-MERGAPTOETHANOL

\begin{tabular}{c|c|c|c|cc}
\hline \multirow{3}{*}{ Exp. } & \multirow{3}{*}{ Enzyme } & \multicolumn{5}{|c}{ Fractions } \\
\cline { 3 - 6 } & & $W$ & $H$ & $R-s u$ & $R-p a$ \\
\hline 3 & AP & 31 & $7 \cdot 7$ & $1 \cdot 1$ & $5 \cdot 8$ \\
& AS & 35 & $3 \cdot 5$ & $0 \cdot 3$ & $0 *$ \\
& $\beta$ A & 285 & $13 \cdot 4$ & $2 \cdot 0$ & 41 \\
4 & PLA & $6 \cdot 1$ & 0.9 & & $7 \cdot 2$ \\
& AP & 40 & $5 \cdot 8 \ddagger$ & $1 \cdot 2$ & 0 \\
& AS $\dagger$ & 0 & $1 \cdot 3$ & $0 \cdot 4$ & 0 \\
& $\beta A$ & 274 & $12 \cdot 6$ & $\underbrace{2 \cdot 4}$ & 40 \\
& PLA & $7 \cdot 2$ & $0 \cdot 6$ & \multicolumn{2}{|c}{$2 \cdot 6$} \\
\hline
\end{tabular}

PLA assays were on freshly prepared fractions: other assays were on frozen fractions. Activities are expressed as in Table 1 (except for PLA where the basis was $\mu$ equiv, of ester hydrolysed in $30 \mathrm{~min}$ ).

* This low value was also obtained with unfrozen fraction $\mathbf{R}$ from a replicate experiment.

$\dagger$ Low values were due to freezing: non-frozen specimens from a replicate experiment yielded the activities 57 for $W$ and 2.3 for $\mathrm{H}$.

$\$$ Values by this procedure were usually around 8 .

TABLE 3

PROTEASE AGTIVITIES AT TWO PH VALUES OF FRAGTions W, $\mathbf{H}$ AND $\mathbf{R}$

\begin{tabular}{c|c|c|c}
\hline \multirow{4}{*}{ Fraction } & \multirow{3}{*}{10 mM-cysteine } & \multicolumn{2}{|c}{ Activity in } \\
\cline { 3 - 4 } & & $\begin{array}{c}0.1 \mathrm{M}-\text { phosphate; } \\
\text { final } p H 7.4\end{array}$ & $\begin{array}{c}0.2 \mathrm{M} \text {-acetate; } \\
\text { final } p H 4.8\end{array}$ \\
\hline $\mathrm{W}$ & + & 30 & 2.4 \\
& - & 15 & 0.9 \\
$\mathrm{H}$ & + & $12 \cdot 6$ & $2 \cdot 7$ \\
& - & 4.3 & 0.9 \\
$\mathrm{R}$ & + & $9 \cdot 3 *$ & $2 \cdot 1 \dagger$ \\
& - & 3.6 & $2 \cdot 1 \dagger$ \\
\hline
\end{tabular}

Activities are expressed as $\Delta E_{280} / 30 \mathrm{~min} / \mathrm{ml}$ of semen but are calculated from changes in $E_{280}$ during the first $15 \mathrm{~min}$.

* Reaction rate increased by $100 \%$ during subsequent $45 \mathrm{~min}$. $\dagger$ Reaction rate fell to a very low level during subsequent 45 min.

Results obtained with fractions isolated (Scheme I) from two batches of pooled ram semen are shown in Table 3 and Text-fig. 1 . Assays of $W, H$ and $\mathrm{R}$ fractions showed higher proteolytic activity at $\mathrm{pH} 7.4$ than at $\mathrm{pH} 4.8$ (Table 
3). Activation by cysteine was apparent in all cases but one. Text-figure 1 shows in more detail the effect of $\mathrm{pH}$ upon the proteolytic activity of an $\mathrm{H}$ fraction. Again, maximum activity is at $\mathrm{pH}>7$ but two minor peaks occur at lower $\mathrm{pH}$ values. We regard these results as typical for $\mathrm{H}$ fractions since similar $\mathrm{pH}$ profiles were frequently obtained. However, on two occasions the $\mathrm{H}$ fractions showed quite different properties.

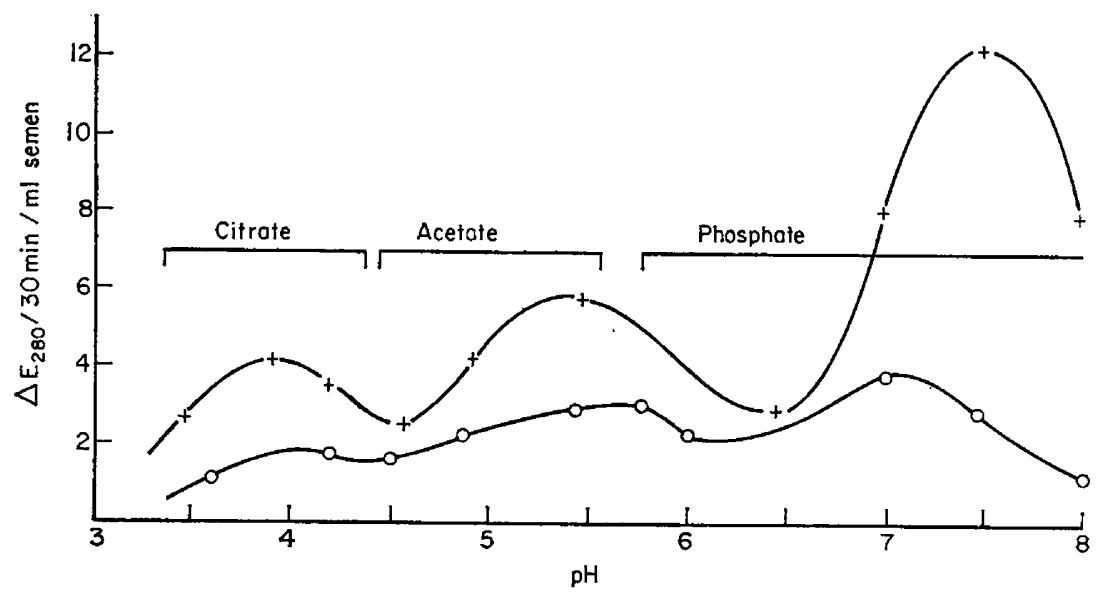

TEXT-FIG. 1. Effect of $\mathrm{pH}$ upon the proteolytic activity of an acrosomal preparation $(\mathrm{H})$. , without cysteine; + , with $10 \mathrm{~mm}$-cysteine. Activities are derived from changes in $E$ during the first $15 \mathrm{~min}$ of the reaction.

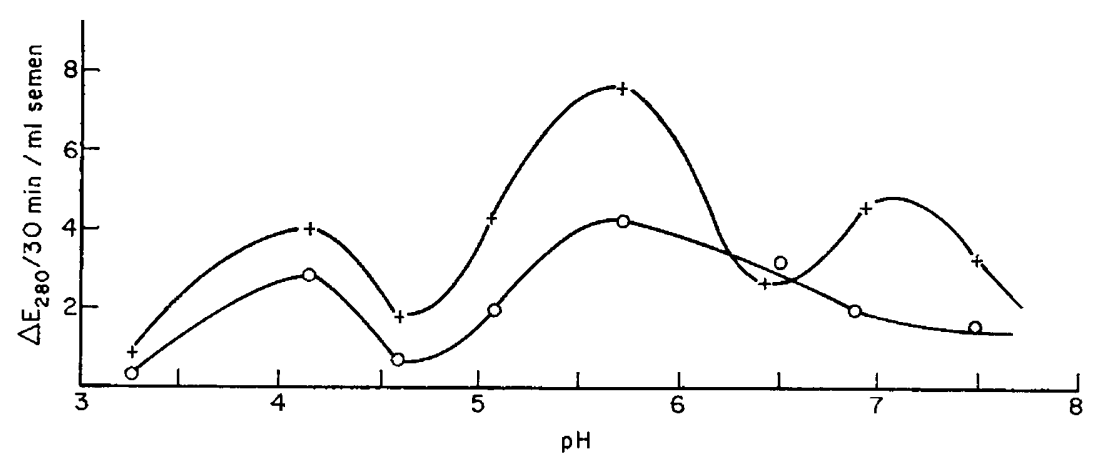

TExT-FIG. 2. Effect of $\mathrm{pH}$ upon the proteolytic activity of an abnormal acrosomal preparation (see text). Activities are derived from changes in $E$ during the first 30 min of the reaction. For further details, see legend to Text-fig. 1.

One 'abnormal' set of $\mathrm{pH}$ profiles is shown in Text-fig. 2. Here there is reversal of the relative heights of the maxima at $\mathrm{pH}$ values 5.4 to 5.6 and 7.2 to 7.5 and a decreased requirement for cysteine at $\mathrm{pH} \sim 4$. However, unlike Text-fig. 1, Text-fig. 2 is based upon measurement of $\Delta E$ ( $E=$ extinction or optical density) during 0 to $30 \mathrm{~min}$. When similar plots were made for the periods (i) 0 to $15 \mathrm{~min}$ and (ii) 15 to $30 \mathrm{~min}$, two marked changes were apparent. One was that the requirement for cysteine at $\mathrm{pH} 4 \cdot 2$ increased with time. 
Thus in (i), the mean rate of proteolysis at $\mathrm{pH} 4.2$ was as high in presence as in absence of cysteine while in (ii), it was only $20 \%$ of the '+cysteine' value. The other change was in the ratio of the activities at $\mathrm{pH} 5.6$ and $\mathrm{pH} 7 \cdot 2$. Initially, these activities were approximately equal but in (ii), the former peak was higher, and the latter peak lower, than in Text-fig. 2. These results suggest that abnormal $\mathrm{H}$ fractions contain a labile factor that can replace cysteine for proteolysis at low $\mathrm{pH}$. They also suggest that the $\mathrm{pH} 5 \cdot 6$ and $\mathrm{pH} 7 \cdot 2$ activities are interconvertible forms of the one protease, which is usually stabilized mainly in the latter form. Lundblad (1954) noticed similar profile variations in a study of the proteases of sea urchin eggs.

\section{Hydrolytic enzymes in semen from vasectomized rams and in seminal plasma from normal rams}

Semen from vasectomized rams showed low activities in all cases (Table 4). While the level of PLA was about $20 \%$ of that in normal semen, the levels of other enzymes were only 0.3 to $1.5 \%$ of normal values. The high activities of $\mathrm{AP}, \beta \mathrm{A}$ and $\mathrm{AS}$ in normal plasma can, in each case, be regarded as mainly soluble since very little activity can be detected in the sediment following centrifugation at $80,000 \mathrm{~g}$.

Table 4

HYDROLASE ACTIVITIES IN SEMEN FROM VASECTOMIZED RAMS AND IN NORMAL SEMINAL PLASMA

\begin{tabular}{|c|c|c|c|}
\hline & \multicolumn{3}{|c|}{ Activity } \\
\hline & \multirow{2}{*}{$\begin{array}{c}\text { Semen from } \\
\text { vasectomized } \\
\text { rams }\end{array}$} & \multicolumn{2}{|c|}{ Normal seminal plasma } \\
\hline & & $\begin{array}{l}\text { Supernatant } \\
\text { fluid }\end{array}$ & Pellet \\
\hline $\begin{array}{l}\text { Acid phosphatase } \\
\text { Aryl sulphatase } \\
\beta \text { - } \mathcal{N} \text {-Acetylglucosaminidase } \\
\text { Phospholipase A } \\
\text { Neutral protease (pH 7.4) } 0 \text { to } 15 \mathrm{~min} \\
15 \text { to } 30 \mathrm{~min} \\
30 \text { to } 45 \mathrm{~min}\end{array}$ & $\begin{array}{l}0.56 \\
0 \cdot 71 \\
0.95 \\
1 \cdot 77 \\
0 \\
0 \cdot 18 \\
0.56\end{array}$ & $\begin{array}{r}73 \\
53 \\
292\end{array}$ & $\begin{array}{l}9 \\
0 \cdot 5 \\
19\end{array}$ \\
\hline
\end{tabular}

The seminal plasma, previously centrifuged at $15,000 \mathrm{~g}$, was re-centrifuged at $80,000 \mathrm{~g}$ for $1 \mathrm{hr}$ to give a supernatant fluid and a very small pellet. Activity: $\mu$ moles substrate hydrolysed $/ 30 \mathrm{~min} / \mathrm{ml}$ of semen except for protease where it is $E_{280} / \mathrm{ml}$ of semen.

Further characterization of enzymes in acrosomal preparations

The phosphatase is a typical acid phosphatase with maximum activity at $\mathrm{pH} 4.5$ and negligible activity at $\mathrm{pH}>7$. The $\mathrm{pH}$ optimum for aryl sulphatase is 4.9. Further examination of aryl sulphatase activity, according to Roy (1955), showed that both A and B forms were present. Using synthetic peptide substrates, cathepsin B was not detected. Cathepsin C activity was detected in one $\mathrm{H}$ preparation but subsequent attempts to detect this protease in $\mathrm{W}, \mathrm{H}$ and $R$ fractions were unsuccessful. 
Malate dehydrogenase activity in $\mathrm{H}$ preparations was at the limit of detection and the proportion of DNA to protein was less than 1 to 50 . Therefore, both mitochondrial and nuclear contamination are very low.

\section{Cytological and histochemical observations}

After vital staining with aminoacridines, the acrosomal fluorescence in ram, bull, boar and human spermatozoa was not very conspicuous. Nuclei fluoresced bright apple green and acrosomes paler green or, with higher concentrations of aminoacridine, pink. Cytoplasmic droplets in ram and bull semen showed green or orange fluorescence. In guinea-pigs (Pl. 1, Fig. 3), hamsters and several laboratory rodents, acrosomes fluoresced brilliant orange-red and were more easily studied by this technique. The opportunity was therefore taken to follow the development of the acrosome in guinea-pig spermatids and compare the fluorescence pattern with the PAS reaction and with histochemical staining for two lysosomal enzymes, acid phosphatase and the esterase that hydrolyses a substituted indoxyl acetate.

In all spermatids, nuclei fluoresced bright apple green, the intensity of fluorescence increasing in the mature spermatids with smaller and more condensed nuclei. In early spermatids, several red-fluorescing granules were observed around a faintly green-fluorescing Golgi zone. Later, these condensed to form a large body, the pro-acrosome, at one pole of the nucleus. Initially, this showed uneven fluorescence, suggesting incomplete fusion of individual bodies; later, it became round and later still, indented on one side as it covered the nucleus. An inner zone closer to the nucleus fluoresced more intensely than an outer zone. The overall fluorescence of the acrosomes in mature spermatids and spermatozoa was less than that in immature spermatids. When spermatids were multinucleate, one acrosome and one other large red fluorescent granule developed in association with each nucleus. For some time the smaller granule remained associated with the mid-piece. Other still smaller granules fluorescing red or green were present in the cytoplasm.

The structure of the pro-acrosome and acrosome, as revealed by the PAS reaction in fixed preparations, was very similar to that given by vital staining with Euchrysine. At all developmental stages, the acrosome gave an unambiguous reaction for chlorobromoindoxyl acetate esterase (Pl. 1, Fig. 4). The reaction product in spermatozoa was confined within the acrosome, leaving a small margin of membrane around the organelle unstained.

Acid phosphatase was clearly demonstrable in the early granules and proacrosome by both the Gomori and Burstone techniques and was usually demonstrable in the developing acrosome. However, the staining at this stage appeared to depend critically on the particular sample of glutaraldehyde used and the fixation time. With fixation for less than $10 \mathrm{~min}$, or longer than $30 \mathrm{~min}$, no reaction product was detectable in acrosomes, although it was visible in cytoplasmic granules and also in the droplets of ram and bull spermatozoa. Ram acrosomal lipoglycoprotein preparations gave reactions for acid phosphatase by both the Gomori and Burstone techniques. These were apparently specific because they were not observed in the absence of glycerophosphate substrate or in the presence of an inhibitor, $10 \mathrm{~mm}$-sodium fluoride. 


\section{DISCUSSION}

\section{Lysosomal enzymes in acrosomes}

Evidence has accumulated that the following enzymes, amongst others, are present in lysosomes: acid phosphatase (de Duve \& Wattiaux, 1966), neuraminidase (Horvat \& Touster, 1968), proteases, aryl sulphatase (Roy, 1960; Rowden, 1967), $\beta$ - $\mathcal{N}$-acetylglucosaminidase (Sellinger, Beaufay, Jacques, Doyen \& de Duve, 1960), phospholipase A (Blaschko, Smith, Winkler, van den Bosch \& van Deenen, 1967; Reinauer, Brügelmann, Kurz \& Hollmann, 1968) and hyaluronidase. There is already evidence for the presence of neuraminidase and hyaluronidase in acrosomes (Hartree \& Srivastava, 1965; Srivastava et al., 1965). The remaining enzymes were, therefore, selected for study since the list includes representatives of acrosomal enzymes that could be involved in breakdown of proteins, carbohydrates and phospholipids, and thus possibly be involved in sperm-egg interaction.

All these enzymes occur in fresh ram semen and in each case, a large proportion is present in the seminal plasma. Among glycosidases, $\beta$ - $N$-acetylglucosaminidase is present at very high concentrations in the male reproductive tract (Conchie \& Mann, 1957). The results and calculations summarized in Table 1 lead to the conclusion that $\mathrm{H}$ fractions are predominantly of spermatozoal origin and that contamination from plasma and droplets is negligible. The low levels of DNA and of mitochondrial enzymes in $\mathrm{H}$ fractions support the earlier conclusion (Hartree \& Srivastava, 1965) that such fractions consist mainly of acrosomal material. It is conceivable that some proteins from seminal plasma might be relatively firmly associated with spermatozoa and less readily removed by washing than is citrate. Since, however, plasma from vasectomized rams had very low activities of lysosomal enzymes, it seems likely that these enzymes in plasma originate from spermatozoa or droplets. Dott \& Dingle (1968) gave a mean value of about 0.17 for the droplet:spermatozoon ratio in bull semen and, on the basis of the level of acid phosphatase in the droplets, they calculated that the plasma acid phosphatase is derived entirely from broken droplets. Some redistribution of enzymes between organelles or fractions might take place during fractionation of semen. Nevertheless, in conventional fractionation of tissues from other organs, such as liver and kidney, there is some loss of enzymes from the particulate (lysosomal) to the supernatant fraction, but acquisition of enzymes by the particulate fraction is not a serious problem. Thus, we conclude that acid phosphatase, $\beta$-N $\mathcal{N}$-acetylglucosaminidase, phospholipase A, protease and probably aryl sulphatase are all constituents of ram acrosomes.

Although major proportions of the enzymic activities in $\mathrm{H}$ fractions are of acrosomal origin, the quoted figures cannot be taken as true values for acrosomes from intact spermatozoa. Treatment with Hyamine detaches only 50 to $60 \%$ of the acrosomes of washed spermatozoa (Hartree \& Srivastava, 1965), while some of the remainder show deformation or partial detachment. Thus, the yield of acrosomal enzymes in the $\mathrm{H}$ fractions, taking $\mathrm{H}+\mathrm{R}$ fractions as 100 , would be 50 to $60 \%$ if only the enzymes of detached acrosomes were recovered in the $\mathrm{H}$ fraction. In fact, the yield is of the order of $50 \%$ for acid phosphatase and for protease but nearly $100 \%$ for aryl sulphatase. This must 
mean that the latter enzyme leaks readily from the still attached acrosomes of Hyamine-treated spermatozoa. Hyaluronidase also leaks freely from spermatozoa (Masaki \& Hartree, 1962) and the possible significance of these observations in relation to the time when enzymes are released in fertilization will be discussed below.

\section{Cytology and histochemistry}

Cytological and histochemical observations provide additional evidence for the lysosomal nature of acrosomes. We have confirmed the observations that acrosomes of spermatozoa in several different species show orange-red fluorescence after vital staining with acridine orange in contrast to the green nuclear fluorescence. This type of red fluorescence was originally thought to be specific for RNA (Armstrong, 1956; Bertalanffy \& Bickis, 1956). However, mature spermatozoa contain, at most, traces of RNA (Bishop \& Walton, 1960); and it is now clear that the red fluorescence observed after staining living, as opposed to fixed, cells with aminoacridines is characteristic of lysosomes (Allison \& Young, 1964, 1969). Lysosomal uptake of aminoacridines is apparently attributable to binding by a specific glycolipid constituent that can be separated by disc electrophoresis (Barrett \& Dingle, 1967). The same component is probably also responsible for the periodic acid-Schiff (PAS) reaction that characterizes lysosomes in many different cell types and is also seen in acrosomes (Clermont \& Leblond, 1955). In the spermatozoa of some species, including man, ram, bull and boar, acrosomal fluorescence after aminoacridine staining is weak, and the same is true of the PAS reaction when compared with that shown by rodent acrosomes. Differences in the concentration of the specific dye-binding glycolipid in acrosomes of different species can perhaps account for these observations.

Most histochemical studies on acrosomes have been concerned with acid phosphatase. There have been reports of the presence of this enzyme in acrosomes of the guinea-pig (Ruffili, 1960), frog (Novikoff, 1961), Triturus cristatus (Buongiorno-Nardelli \& Bertolini, 1967) and the rat (Buongiorno-Nardelli \& Nicholson, 1967). Although Dalcq $(1963,1967)$ found acid phosphatase in the acrosomal precursors of rodents, he was unable to demonstrate the enzyme in mature acrosomes. In our hands, the reaction in acrosomal precursors in guinea-pig spermatids has been more consistently demonstrable than in mature acrosomes. The latter has depended critically on fixation time and on the particular sample of glutaraldehyde. Nevertheless, we have no doubt that under favourable conditions, the enzyme is demonstrable in acrosomes of rodents and also in $\mathrm{H}$ fractions of ram acrosomes.

The other acrosomal enzyme which has been studied histochemically is esterase. The presence of non-specific esterase in guinea-pig acrosomes was illustrated by Birns \& Masek (1961), and Dalcq (1967) has reported the presence of 5-bromo-indoxylacetate esterase in guinea-pig acrosomes. We have consistently found 5-bromo-4-chloroindoxylacetate esterase in guinea-pig acrosomes, provided that the fixation time is short. Since this enzyme is characteristically lysosomal in other tissues (Holt, 1963), its presence in acrosomes provides further support for the view that these organelles are related. 
Rôle of the acrosome in fertilization

The term 'acrosome reaction' has been used to describe two distinct though related phenomena that are characteristic of invertebrate spermatozoa. These are (1) formation of a rod-like structure which appears to carry egg-lysins through the jelly coat of sea urchin eggs to the egg membrane (Dan, 1967), and (2) a fusion of acrosomal and egg membranes leading to passage of the sperm nucleus into the egg (Austin, 1965; Colwin \& Colwin, 1967). Bedford (1968) has demonstrated that when a rabbit spermatozoon penetrates the mass of follicular cells surrounding newly ovulated rabbit eggs, the sperm plasma membrane and outer acrosomal membrane fuse to form vesicles. Only the inner acrosomal membrane remains in situ when the spermatozoon reaches the zona pellucida. Bedford suggests that the process may be linked to sequential, or at least bimodal, release of enzymes. Thus, hyaluronidase would be released at the vesiculation stage as the spermatozoon moves into the cumulus oophorus, while enzymes such as protease would be bound to the inner acrosomal membrane and so become available to facilitate penetration of the zona pellucida. Removal of the follicular cells that surround freshly ovulated rodent eggs can be brought about by successive treatments with hyaluronidase which disperses the cumulus oophorus (Swyer, 1947), and of proteases which remove the corona radiata (Gwatkin, 1964). Since acrosomal preparations can simulate the effects of these treatments and can also cause breakdown of the zona pellucida (Srivastava et al., 1965), it seems reasonable to regard the acrosome as a specialized lysosome which evolved to facilitate fertilization in multicellular organisms.

The concept of sequential release of enzymes from the acrosome receives some support from our biochemical and histochemical observations. Sulphatase can be extracted from non-detached acrosomes and, like the readily released hyaluronidase, might conceivably contribute to the dispersal of the cumulus oophorus, although in the absence of knowledge of the natural sulphatase substrate, there is no evidence for this at present. Other enzymes, such as protease and phosphatase, can be extracted to an extent that is consistent with the proportion of acrosomes that are dislodged by Hyamine, i.e. of acrosomes with inner membranes presumably exposed. The esterase and acid phosphatase reaction products are confined within the outer acrosomal membranes, which would also be consistent with a relationship to the inner membrane. Further electron microscopical observations, relating the fine structure of the acrosome to sequential release of enzymes, should help to clarify the position.

\section{ACKNOWLEDGMENTS}

We wish to thank Mr G. R. Brown and Mr M. R. Young for help with the experiments, Dr H. M. Dott for valuable discussions, and Professor T. Mann, F.R.S., for his advice and encouragement. We also wish to thank Dr J. M. Bedford for supplying details of his unpublished experiments.

\section{REFERENCES}

Alzison, A. G. \& Hartree, E. F. (1968) Lysosomal nature of the acrosomes of ram spermatozoa. Biochem. J. 111, 35P. 
Alrison, A. C. \& Mallucar, L. (1965) Histochemical studies of lysosomes and lysosomal enzymes in virus-infected cell cultures. 7. exp. Med. 121, 463.

Allison, A. G. \& Young, M. R. (1964) Uptake of dyes and drugs by living cells in culture. Life Sci. 3, 1407.

Allison, A. C. \& Young, M. R. (1969) Vital staining and fuorescence microscopy of lysosomes. In: The Role of Lysosomes in Biology and Pathology, vol. II. Eds. J. T. Dingle and H. B. Fell. North Holland Publishing Co., Amsterdam, p. 600.

Armstrong, J. A. (1956) Histochemical differentiation of nucleic acids by means of induced fluorescence. Expl Cell Res. 11, 640.

Aronson, N. N. \& Davidson, A. (1965) Lysosomal hyaluronidase. F. biol. Chem. 240, PC3222.

Aronson, N. N. \& Davidson, E. A. (1968) Catabolism of mucopolysaccharides by rat liver lysosomes in vivo. F. biol. Chem. 243, 4494.

Austis, C. R. (1965) Ultrastructural changes in the egg during fertilization and the initiation of cleavage. Ciba Fdn Symp. on Preimplantation Stages of Pregnancy. Eds. G. E. W. Wolstenholme and M. O'Connor. Churchill, London.

Barrett, A. J. \& Dingle, J. T. (1967) A lysosomal component capable of binding cations and a carcinogen. Biochem. $\mathcal{F} .105,20 \mathrm{P}$.

Beare, J. L. \& Kates, M. (1967) Properties of the phospholipase B from Penicillium notatum. Can. $\mathcal{F}$. Biochem. 45, 101.

BEDFORD, J. M. (1968) Ultrastructural changes in the sperm head during fertilization in the rabbit. Am. F. Anat. 123, 329.

Bergmeyer, H. U. (1963) Methods of enzymatic analysis, p. 783. Academic Press, London.

BERTALANFFY, L. vON \& BICKIS, I. (1956) Identification of cytoplasmic basophilia (ribonucleic acid) by fluorescence microscopy. F. Histochem. Cytochem. 4, 481 .

BrRns, M. \& MAseK, B. (1961) Localization of enzyme activities in frozen substituted fixed cells. $\mathcal{J}$. Histochem. Cytochem. 9, 204.

Bishor, M. W. H. \& SMILES, J. (1957) Induced fluorescence in mammalian gametes with acridine orange. Nature, Lond. 179, 307.

Bishop, M. W. H. \& SMiLes, J. (1963) Differentiation of the acrosome in living mammalian spermatozoa and spermatids by fluorescence microscopy. F. Reprod. Fert. 6, 297.

Bishop, M. W. H. \& Walton, A. (1960) Spermatogenesis and the structure of mammalian spermatozoa. In: Marshall's Physiology of Reproduction, 3rd edn, Vol. 1, part 2. Ed. A. S. Parkes. Longmans Green, London.

Blaschko, H., Smith, A. D., Winkler, H., van den Bosch, H. \& van Deenen, L. L. M. (1967) Acid phospholipase A in lysosomes of the bovine adrenal medulla. Biochem. $7.103,30 \mathrm{c}$.

Bouma, J. M. W. \& Gruber, M. (1964) The distribution of cathepsins B and C in rat tissues. Biochim. biophys. Acta, 89, 545 .

BuONGioRno-NARDELII, M. \& Bertolini, B. (1967) Subcellular localization of some acid hydrolases in Triturus cristatus spermatozoa. Histochemie, 8, 34.

Buongiorno-Nardeli, M. \& Nicholson, A. (1967) Studio istochimico della spermioistogenesi di ratto. Riv. istoch. norm. Pat. 12, 333.

Burstone, M. S. (1961) Histochemical demonstration of phosphatases in frozen sections with naphthol AS-phosphates. 7. Histochem. Cytochem. 9, 146.

Burton, K. (1956) A study of the conditions and mechanism of the diphenylamine reaction for the colorimetric estimation of deoxyribonucleic acid. Biochem. F. 62, 315.

Clermont, Y. \& Leblond, C. P. (1955) Spermiogenesis of man, monkey, ram and other mammals as shown by the 'periodic acid-Schiff' technique. Am. F. Anat. 96, 229.

Colwin, L. H. \& Colwin, A. L. (1967) Fertilization. Comparative morphology, biochemistry and immunology, vol. 1, p. 295. Eds. G. B. Metz and A. Monroy. Academic Press, New York.

Conchie, J. \& ManN, T. (1957) Glycosidases in mammalian sperm and in seminal plasma. Nature, Lond. 179, 1190.

DALCQ, A. M. (1963) The relationship to lysosomes of the in vivo metachromatic granules; also in Discussion, p. 309. Ciba Fdn Symp. Lysosomes. Eds. A. V. S. de Rueck and M. P. Cameron. Churchill, London.

DALcQ, A. M. (1967) Les recherches récentes sur la formation du testicule des mammifères et sur la cytologie de ses constituants. Bull. Acad. Rle. Med. 3, 1.

DAN, J. C. (1967) Fertilization. Comparative morphology, biochemistry and immunology, vol. 1, p. 237. Eds. G. B. Metz and A. Monroy. Academic Press, New York.

DE Duve, G. \& Wattiaux, R. (1966) Functions of lysosomes. A. Rev. Physiol. 28, 435.

Dott, H. M. \& Dingle, J. T. (1968) Distribution of lysosomal enzymes in the spermatozoa and cytoplasmic droplets of bull and ram. Expl Cell Res. 52, 523.

FiLIPović, I. \& BuDDECKE, E. (1968) Wechselseitige Aktivierung und intrazelluläre Lokalisation von Hyaluronidase und Kathepsin D aus Rindermilz. Hoppe-Seyler's Z. physiol. Chem. 349, 533. 
FindLAY, J., Levvy, G. A. \& MARsh, G. A. (1958) Inhibition of glycosidases by aldonolactones of corresponding configuration. 2. Inhibitors of $\beta-\mathcal{N}$-acetylglucosaminidase. Biochem. F. 69, 467.

Gallai-Hatchard, J. J. \& Thompson, R. H. S. (1965) Phospholipase-A activity of mammalian tissues. Biochim. biophys. Acta, 98, 128.

Gwatkin, R. B. L. (1964) Effect of enzymes and acidity on the zona pellucida of the mouse egg before and after fertilization. F. Reprod. Fert. 7, 99.

Hartree, E. F. \& Srivastava, P. N. (1965) The chemical composition of the acrosomes of ram spermatozoa. F. Reprod. Fert. 9, 47.

HoLt, S. J. (1958) Indigogenic staining methods for esterases. Gen. cytochem. Meth. 1, 375.

HoLt, S. J. (1963) Some observations on the occurrence and nature of esterases in lysosomes. Ciba Fdn Symp. Lysosomes. Eds. A. V. S. de Rueck and M. P. Cameron. Churchill, London.

Horvat, A. \& Touster, O. (1968) On the lysosomal occurrence and the properties of the neuraminidase of rat liver and of Ehrlich ascites tumor cells. F. biol. Chem. 243, 4380.

HutTerer, F. (1966) Degradation of mucopolysaccharides by hepatic lysosomes. Biochim. biophys. Acta, 115, 312.

Lundblad, G. (1954) Proteolytic activity in sea urchin gametes. IV. Further investigations of the proteolytic enzymes of the egg. Ark. Kemi, 7, Nr. 17.

MANN, T. (1946) Studies on the metabolism of semen. 3. Fructose as a normal constituent of seminal plasma. Site of formation and function of fructose in semen. Biochem. $7.40,481$.

ManN, T. (1964) Biochemistry of semen and of the male reproductive tract. Methuen, London.

MASAKI, J. \& HARTREe, E. F. (1962) Distribution of metabolic activity, phospholipid and hyaluronidase between the heads and tails of bull spermatozoa. Biochem. 7. 84, 347 .

Mehler, A. H., Kornberg, A., Grisolia, S. \& OchoA, S. (1948) The enzymatic mechanism of oxidoreductions between malate or isocitrate and pyruvate. 7 . biol. Chem. 174, 961 .

Novikoff, A. B. (1961) Observations on the Golgi apparatus and related lysosomes. Biol. Bull. mar. biol. Lab., Woods Hole, 121, 369.

Pearse, A. G. E. (1968) Histochemistry, vol. 1. Churchill, London.

Press, E. M., Porter, R. R. \& Cebra, J. (1960) The isolation and properties of a proteolytic enzyme, cathepsin D, from bovine spleen. Biochem. F. 74, 501 .

Reinauer, H., Brügelmann, J., Kurz, W. \& Hollmann, S. (1968) Zur subzellulären Lokalisation der Phospholipasen in der Milz der Ratte. Hoppe-Seyler's Z. physiol. Chem. 349, 1191.

Rowden, G. (1967) Lysosomal aryl sulphatase in mouse kidney and liver. Nature, Lond. 215, 1283.

Roy, A. B. (1955) The sulphatase of ox-liver. 4. A note on the inhibition of sulphatases A and B. Biochem. 7. 59, 8.

Roy, A. B. (1960) The sulphatase of ox liver. 7. The intracellular distribution of sulphatases A and B. Biochem. 7. 77, 380.

Ruffili, A. (1960) La fosfatasi acida nell'acrosoma degli spermatidi e nel reticolo di Golgi della cellule dell'epididimo di cavia. Ricerca scient. 30, 145.

Sellinger, O. Z., Beaufay, H., Jaceues, P., Doyen, A. \& de Duve, G. (1960) Tissue fractionation studies. 15. Intracellular distribution and properties of $\beta$ - $\mathcal{N}$-acetylglucosaminidase and $\beta$ galactosidase in rat liver. Biochem. F. 74, 450.

Srivastava, P. N., Adams, C. E. \& Hartree, E. F. (1965) Enzymic action of acrosomal preparations on the rabbit ovum in vitro. F. Reprod. Fert. 10,61.

SwYER, G. I. M. (1947) A tubal factor concerned in the denudation of rabbit ova. Nature, Lond. 159, 873.

VAEs, G. (1967) Hyaluronidase activity in lysosomes of bone tissue. Biochem. F. 103, 802. 